\title{
Saudi Arabian expatriate worker fitness-screening programme: a review of 14 years of data
}

\author{
F.M. Alswaidi, ${ }^{1}$ Z.A. Memish, ${ }^{7}$ R.F. Al-Hakeem ${ }^{1}$ and S.A. Atlam ${ }^{7}$
}

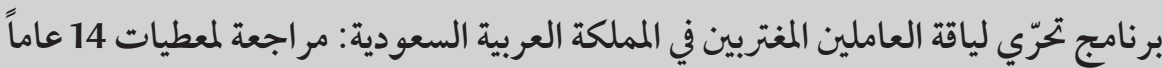

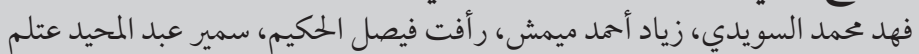

الخلاصـة: ينبغي أن يخضع العاملون الو افدون لفحص طبي في بلدانهم الأصلية ضمن مراكز معتمدة قبل وصو لهم إلى بلدان مجلس التعاون الخليجي.

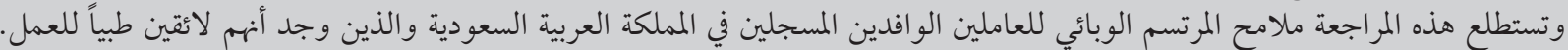

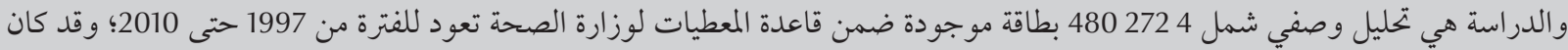

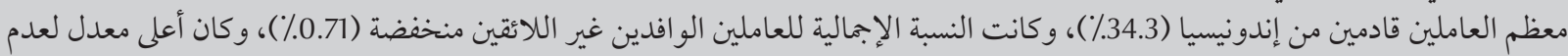

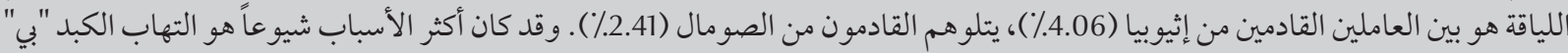

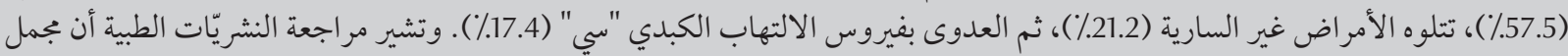

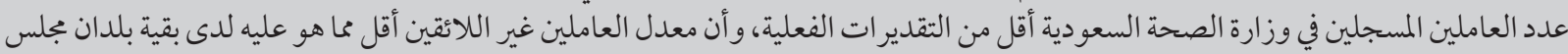

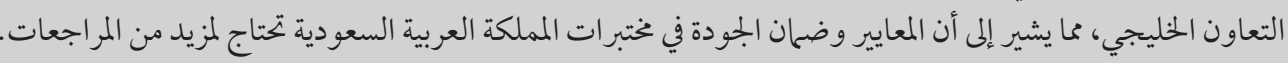

ABSTRACT Expatriate workers must be medically examined in their country of origin at accredited centres prior to their arrival in any Gulf Cooperation Council (GCC) country and are reexamined when they enter the country. This review investigated the epidemiological profile of registered expatriate workers in Saudi Arabia who were found medically unfit to work. A descriptive analysis was performed on 4272480 records of a Ministry of Health database from 1997 to 2010. The greatest proportion of workers was from Indonesia (34.3\%). The total proportion of unfit expatriate workers was low (0.71\%). The highest rate of unfitness was among workers from Ethiopia (4.06\%), followed by Somalia (2.41\%). Hepatitis B infection was the most common cause (57.5\%), followed by noncommunicable diseases (21.2\%) and hepatitis $\mathrm{C}$ infection (17.4\%). This review suggests that the total number of workers registered in the Saudi Ministry of Health was underestimated, and the rate of unfit workers was lower than for other GCC countries, suggesting that standards and quality assurance in Saudi laboratories require revision.

Programme saoudien d'évaluation des aptitudes physiques des travailleurs expatriés : examen de 14 années de données

RÉSUMÉ Les travailleurs expatriés doivent passer une visite médicale dans leur pays d'origine, dans un centre accrédité avant leur arrivée dans un pays du Conseil de coopération du Golfe, et sont ensuite réexaminés sur place. Le présent examen portait sur le profil épidémiologique des travailleurs expatriés enregistrés en Arabie saoudite qui avaient été déclarés médicalement inaptes au travail. Une analyse descriptive de 4272480 dossiers, issus d'une base de données du ministère de la Santé, entre 1997 et 2010 a été réalisée. La plus importante part des travailleurs venait d'Indonésie (34,3\%). La proportion totale de travailleurs expatriés inaptes était faible $(0,71 \%)$. Le taux d'inaptitude le plus élevé a été observé chez les travailleurs éthiopiens (4,06\%), et somaliens (2,41 \%). L'infection par le virus de l'hépatite B était la cause la plus fréquente (57,5 \%), suivie par les maladies non transmissibles (21,2\%) et l'infection par le virus de l'hépatite C (17,4\%). Cette analyse semble indiquer que le nombre total de travailleurs enregistrés au ministère de la Santé saoudien était sous-estimé et que le taux de travailleurs inaptes est inférieur à celui des autres pays du Conseil de coopération du Golfe, ce qui donne à penser qu'une révision des normes et de l'assurance qualité des laboratoires saoudiens est nécessaire. 


\section{Introduction}

With the globalization of the oil and gas industries in the late 1970s, Saudi Arabia became an important destination for many expatriate workers from many nations [1,2]. In 1983 the health authorities in Saudi Arabia, in compliance with the regulations and recommendations of the World Health Organization (WHO), started to perform mandatory medical screening on all expatriate workers. In Saudi Arabia this screening programme is seen an important strategy for preventing the spread of communicable diseases due to the higher numbers of expatriate workers and their dependants $(31.1 \%$ of the total population in Saudi Arabia) [3]; the high rates of communicable diseases in many of the countries of origin; and the nature of the work of some expatriates (e.g. housemaids, health workers, private drivers and food handlers), which brings them into direct contact with Saudi citizens [4].

In 1995, the executive board of health ministers for the Gulf Cooperation Council (GCC) took responsibility for publicizing and implementing the rules and regulations for medical examinations of expatriate workers in all GCC countries $[3,5]$. Under the scheme expatriate workers must be medically examined and tested in their country of origin at accredited centres, prior to their arrival in a GCC country. All expatriate workers are reexamined on arrival in Saudi Arabia. This is a prerequisite to issue their stay permits. Their health screening results are compared with the medical certificates issued in their country of origin. The executive board of health ministers for GCC countries arranges for annual (unannounced) visits to accredited centres to ensure implementation of unified standards. Violations within a centre may result in penalties, including the withdrawal of accreditation or fines if an expatriate worker who holds a fitness certificate from one of these centres is subsequently identified as unfit in the Saudi fitness-screening programme [6].

There are important epidemiological indicators among expatriate workers in Saudi Arabia, e.g. their nationality distribution, the magnitude, distribution and causes of their medical unfitness and the trends of disease among them. This review was made to investigate the epidemiological profile of registered expatriate workers in Saudi Arabia who were found to be medically unfit for work.

\section{Methods}

A systematic review was conducted in the Ministry of Health (MOH) electronic database of the available and accessible data for the Saudi expatriate worker fitness-screening programme. Data from each year of a 14-year period (1997-2010) were compared with paper records. Incomplete data were requested from the regional coordinators. Microsoft Excel software was used to pool data for all years and for the subsequent analysis. A descriptive analysis was carried out and the results presented in distribution tables and graphs.

A literature search of the screening of expatriates was limited to the early 1980s and 2000s, when screening began in Saudi Arabia. The review included published books, reports and articles on the web or in print.

\section{Results}

\section{Background data}

In this review, the total number of registered expatriate workers re-examined in Saudi Arabia was 4272 480. The average number examined each year was 305 177. The number of workers tested over the study period varied in each year, but generally increased slightly over time. The highest number of examinations took place in 2010, and the lowest in 2007 (Figure 1). The majority of workers examined (3970 875, 93.1\%) were men, and the male to female ratio was nearly 13:1 (Table 1). The highest proportion of expatriates came from Indonesia (34.2\%), with the smallest proportion from Somalia (0.08\%). The highest proportion of

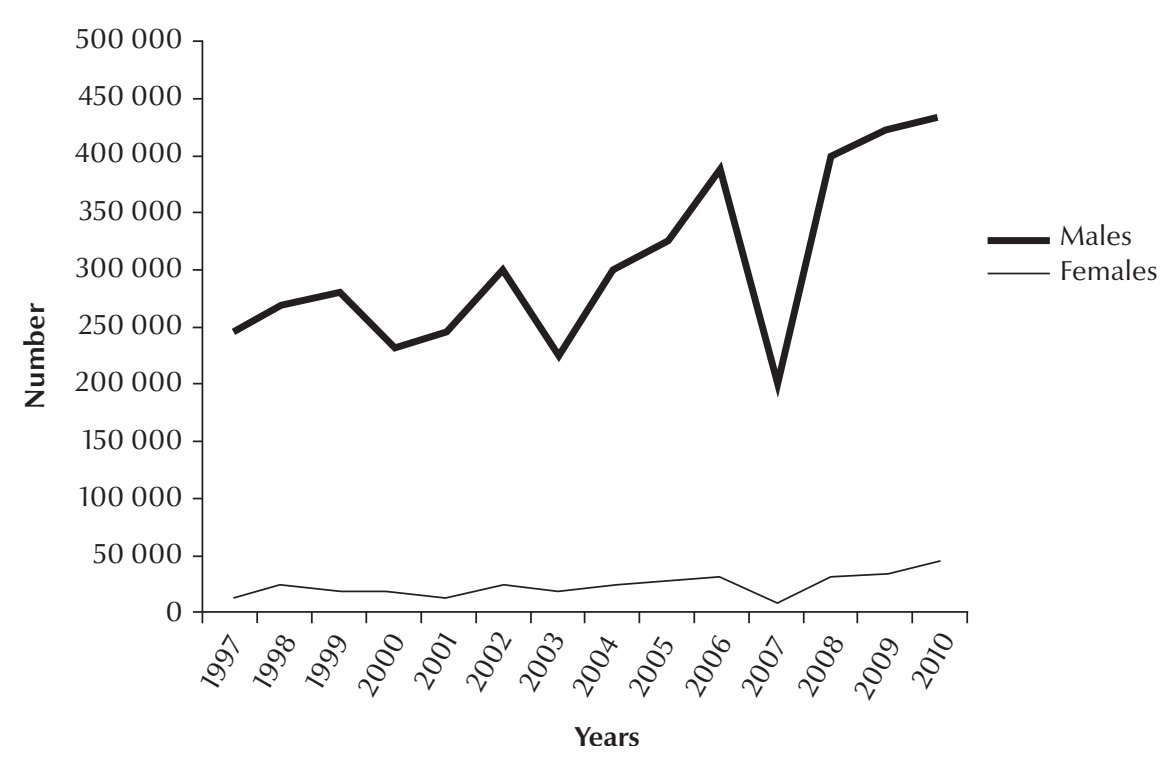

Figure 1 Annual number of expatriate workers examined in Saudi Arabia over the period 1997-2010 


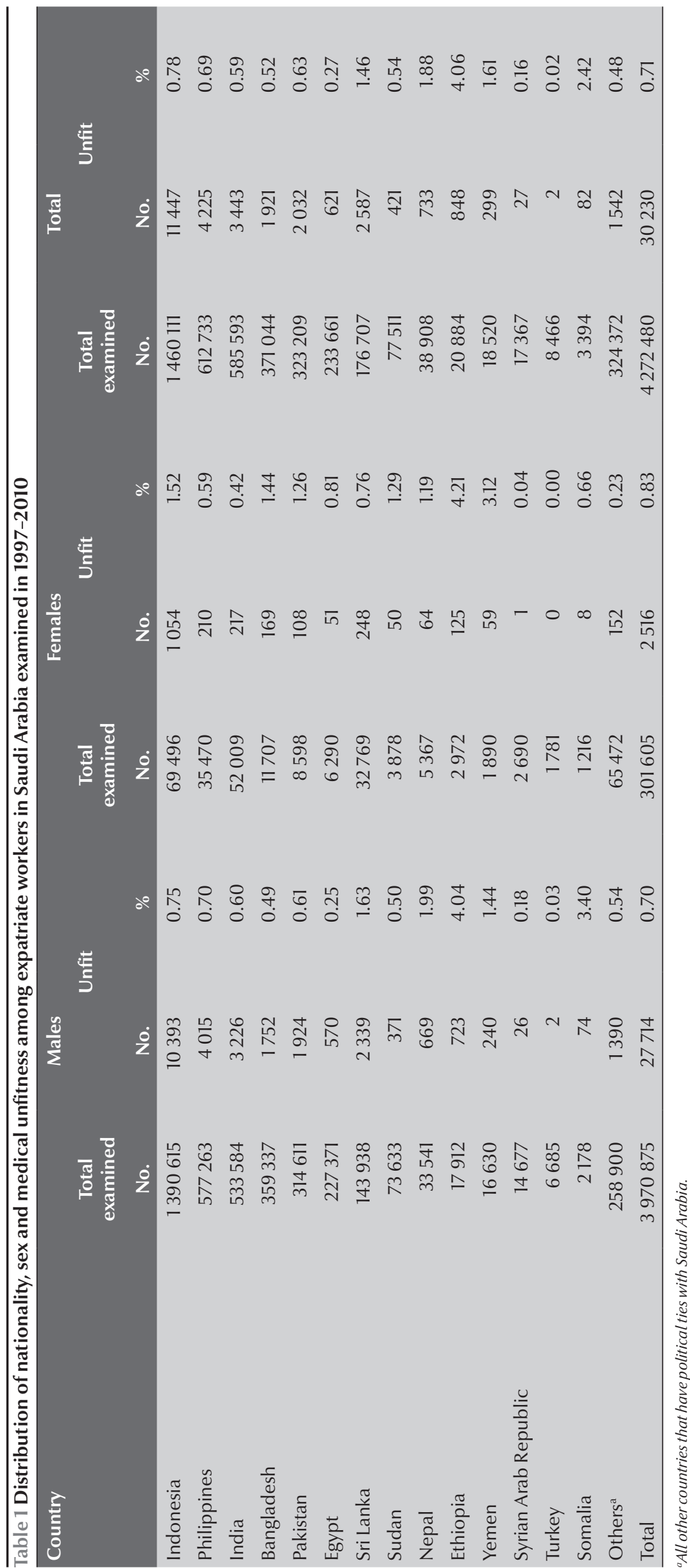

women came from Somalia (35.8\%), and the lowest from Egypt and Pakistan (2.7\% each)

\section{Prevalence of unfitness}

Over the study period, a total of 30230 workers $(0.71 \%)$ were found to be unfit to work. Most of them (27 714, $91.7 \%)$ were men. The highest rate of unfitness was among Ethiopian workers (4.06\%), followed by those from Somalia $(2.42 \%)$ and Nepal (1.88\%), with the lowest rate found in workers from Turkey (0.02\%) (Table 1). Throughout the first 10 years of the period studied, there was little variation in the numbers of unfit workers. In 2007 there was a sudden decrease, and this was followed by a significant increase in 2008 , which peaked in 2010 (Figures 1 and 2).

\section{Causes of unfitness}

Among the total 30230 unfit workers hepatitis B virus (HBV) infection was the most common cause of unfitness (17371 cases, 57.5\%), followed by chronic (noncommunicable) diseases (pooled data) (6581, 21.8\%), hepatitis $\mathrm{C}$ virus (HCV) infection (5265, $17.4 \%)$ and human immunodeficiency virus (HIV) infection (413, 1.4\%). The numbers of workers with infection and chronic diseases during the period studied are shown in Figure 2.

\section{Infectious diseases}

The total number of workers with infectious diseases was 23649 and 21665 (91.7\%) were men (Table 2). The average annual number of workers with HBV was 1150, followed by 500 cases of HCV, 86 of TB and 35 of HIV. The highest rates of HBV were in workers from Indonesia (29.9\%) and the Philippines (13.0\%); the lowest rate was among Turkish expatriates $(0.01 \%)$ (Table 2). The highest rates of $\mathrm{HCV}$ were also found in workers from Indonesia (7.22\%) and the Philippines (3.32\%). There were no cases from Turkey. The highest rates of HIV infection were in workers from Indonesia 

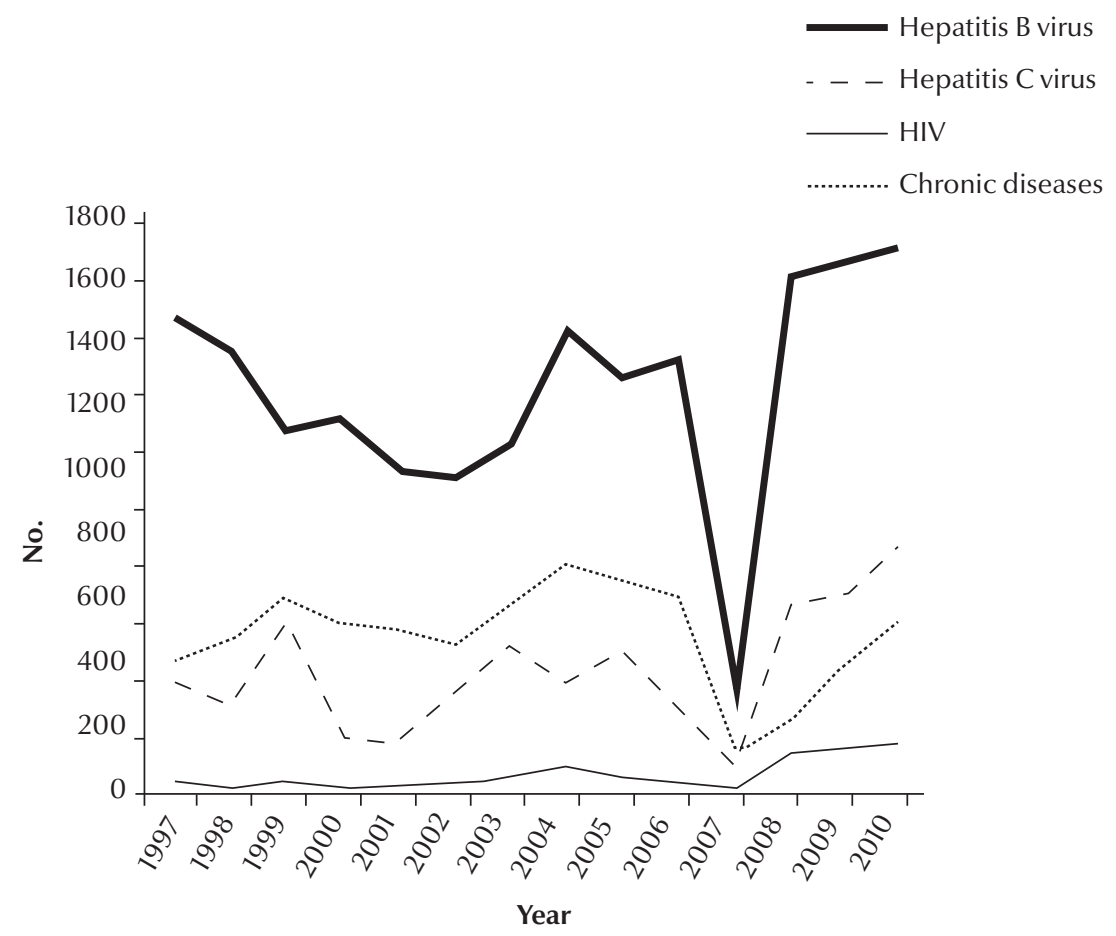

Figure 2 Main causes of unfitness (diseases) among expatriate workers examined in Saudi Arabia over the period 1997-2010

(0.78\%) and the Philippines (0.32\%) (Table 2).

\section{Noncommunicable diseases}

Among the 6581 expatriates who were unfit to work due to chronic (noncommunicable) diseases, 6049 (91.9\%) were men (Table 3). Diabetes mellitus and hypertension were the most common problems (95.7\%). The highest rates of these diseases were found in workers from Indonesia (36.4\%) and India (17.6\%). The occurrence of neoplastic and neuropsychiatric diseases was very low in workers from Indonesia. Among the women registering pregnancy as their cause of medical unfitness, the greatest number were from the Philippines (1.79\%) (Table 3).

\section{Discussion}

The data for this review were obtained from records over a 14-year period from 1997, when electronic data collection started in Saudi Arabia, to 2010. This long time period allowed a reasonable assessment of the time trends to be made. The increase in the number of expatriate workers arriving in Saudi Arabia from 2005 onwards may be due the influx of workers from new sources, such as China, Nepal, Viet Nam, Ethiopia and Eritrea, which were added to the programme around 2005. The sudden and transient decrease observed in worker numbers in 2007 may relate to the start of the online registration process. The staff responsible for online registration may not have been adequately prepared or trained, and the online facilities may have been insufficient at that time. Thereafter, the numbers registered returned to preonline levels. Workers from Indonesia represented the majority of expatriates, probably because families in Saudi Arabia prefer to employ Indonesian workers as housemaids and private drivers [7-10].

Most expatriate workers were men. Women, who accounted for $7 \%$ of the total, are usually employed as housemaids or health-care workers $[11,12]$.
Approximately one-third of workers from Somalia were females; this is the country from which the highest proportion of women come, and may be a result of the ongoing conflict in Somalia that has forced many families to leave the country.

Ideally, there should be no unfit cases at the time of re-screening in Saudi Arabia. The data showed this was not the case. Although the rate of unfitness was only $0.71 \%$ this represents a total of 30230 workers who were unfit to work. This discrepancy raises issues regarding the accuracy and quality of testing in the countries of origin. In general, the highest specific unfitness rates were found among workers from Africa. This was expected because of the limited medical care available in African countries [13]. Recent WHO reports show that some of the highest prevalence rates of HIV infection, HBV, HCV and TB are in Horn of Africa countries [14-16]. These countries would benefit from efforts directed at ensuring the quality and accuracy of their medical testing procedures.

The average annual number of expatriates who were unfit to work due to infectious diseases was found to be lower in this study than in the official $\mathrm{MOH}$ statistics, especially for HIV (413 cases), HCV (5265 cases) and TB (257 cases) $[17,18]$. However, the non-Saudi individuals included in the $\mathrm{MOH}$ statistics may have lived in Saudi Arabia for many years and may have acquired their infection after arriving in the country. Therefore, these data cannot be compared with data from the expatriate screening programme. For the same reason, the figures regarding non-infectious diseases cannot be compared. Data on the regional distribution of unfit workers was not available because of technical problems in the computerized reporting system.

HBV was the most common cause of unfitness among all the workers in this study. This was followed by chronic diseases and HCV. The pattern of these 


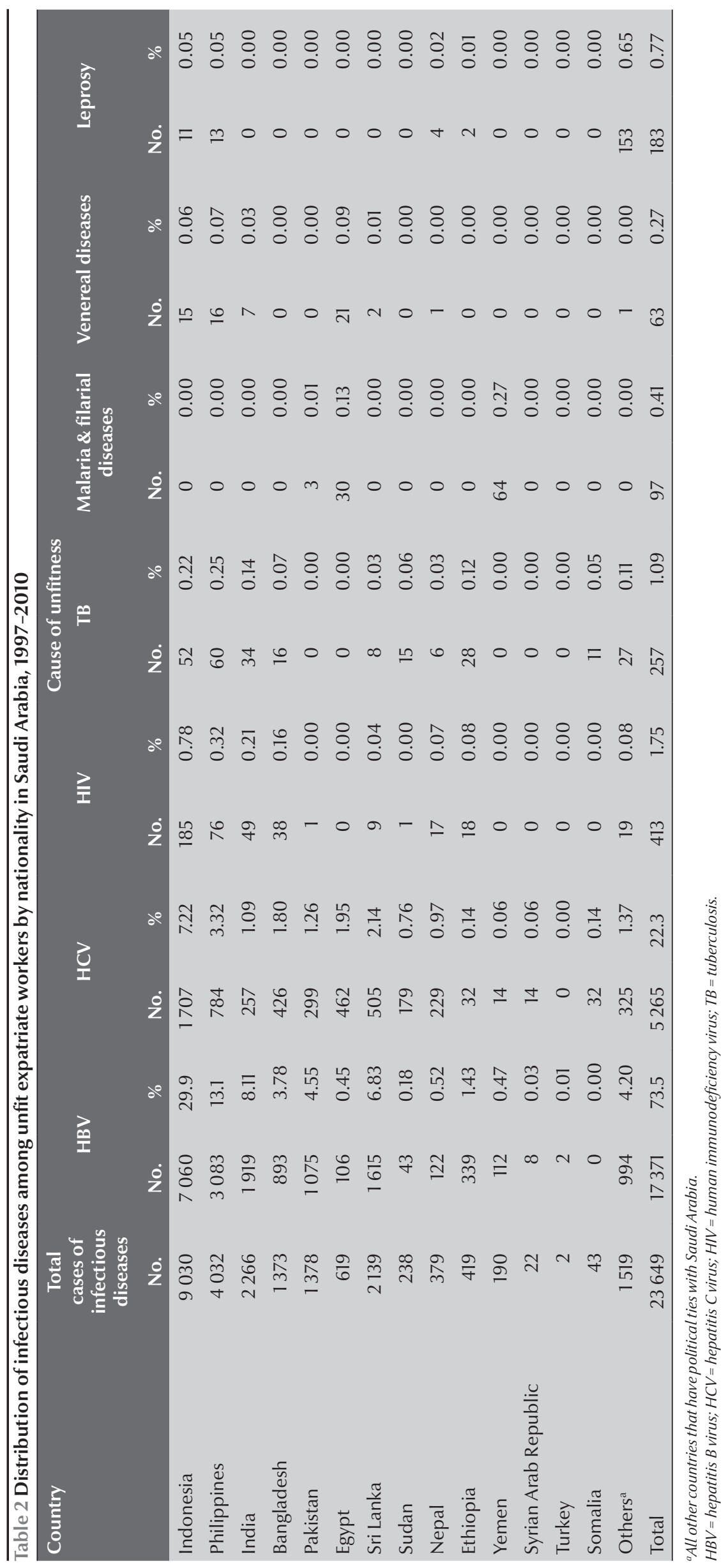




\begin{tabular}{|c|c|c|c|c|c|c|c|c|c|}
\hline \multirow[t]{3}{*}{ Country } & \multirow{3}{*}{$\begin{array}{c}\text { Total cases } \\
\text { of non- } \\
\text { communicable } \\
\text { disease } \\
\text { No. }\end{array}$} & \multicolumn{8}{|c|}{ Cause of unfitness } \\
\hline & & \multicolumn{2}{|c|}{$\begin{array}{l}\text { Chronic } \\
\text { disease }^{\text {a }}\end{array}$} & \multicolumn{2}{|c|}{ Neoplasms } & \multicolumn{2}{|c|}{$\begin{array}{c}\text { Neuropsychiatric } \\
\text { diseases }\end{array}$} & \multicolumn{2}{|c|}{ Pregnancy } \\
\hline & & No. & $\%$ & No. & $\%$ & No. & $\%$ & No. & $\%$ \\
\hline Indonesia & 2417 & 2397 & 36.40 & 0 & 0.00 & 18 & 0.27 & 2 & 0.03 \\
\hline Philippines & 193 & 61 & 0.93 & 3 & 0.05 & 11 & 0.17 & 118 & 1.79 \\
\hline India & 1177 & 1156 & 17.60 & 0 & 0.00 & 0 & 0.00 & 21 & 0.32 \\
\hline Bangladesh & 548 & 528 & 8.02 & 0 & 0.00 & 0 & 0.00 & 20 & 0.30 \\
\hline Pakistan & 654 & 640 & 9.72 & 1 & 0.02 & 0 & 0.00 & 13 & 0.20 \\
\hline Egypt & 2 & 0 & 0.00 & 2 & 0.03 & 0 & 0.00 & 0 & 0.00 \\
\hline Sri Lanka & 448 & 405 & 6.15 & 0 & 0.00 & 4 & 0.06 & 39 & 0.59 \\
\hline Sudan & 183 & 183 & 2.78 & 0 & 0.00 & 0 & 0.00 & 0 & 0.00 \\
\hline Nepal & 354 & 339 & 5.15 & 0 & 0.00 & 1 & 0.02 & 14 & 0.21 \\
\hline Ethiopia & 429 & 429 & 6.52 & 0 & 0.00 & 0 & 0.00 & 0 & 0.00 \\
\hline Yemen & 109 & 109 & 1.66 & 0 & 0.00 & 0 & 0.00 & 0 & 0.00 \\
\hline Syrian Arab Republic & 5 & 4 & 0.06 & 1 & 0.02 & 0 & 0.00 & 0 & 0.00 \\
\hline Turkey & 0 & 0 & 0.00 & 0 & 0.00 & 0 & 0.00 & 0 & 0.00 \\
\hline Somalia & 39 & 39 & 0.59 & 0 & 0.00 & 0 & 0.00 & 0 & 0.00 \\
\hline Others & 23 & 6 & 0.09 & 0 & 0.00 & 9 & 0.14 & 8 & 0.12 \\
\hline Total & 6581 & 6296 & 95.70 & 7 & 0.11 & 43 & 0.65 & 235 & 3.57 \\
\hline
\end{tabular}

${ }^{a}$ Mainly diabetes mellitus, hypertension, other liver and kidney diseases.

diseases among workers is consistent with the pattern of disease in most Asian and African countries where infectious diseases are more common [13]. Workers from Indonesia and the Philippines had the highest specific rate of unfitness due to HIV, HBV and HCV and chronic diseases. Although the prevalence of HIV and hepatitis infections is high in South-East Asia [19-21] the rate of HIV cases among Africans was higher than that for South-East Asians in our study.

The rates of unfit expatriate workers in other GCC countries, namely United Arab Emirates and Kuwait, have been reported as 3.2\% and $4.1 \%$ respectively $[22,23]$. These are considerably higher than that in our review of Saudi Arabia (0.71\%). One reason for this difference might be that the quality of re-examinations in the other GCC countries is better than that in Saudi Arabia. An investigation into the technical quality standards and procedures of the designated Saudi laboratories might be warranted on this basis. Despite the relatively low rate of unfit workers identified in our study and throughout GCC countries, there is a sound rationale to revise and supervise the accredited testing centres in the countries of origin.

The total number of registered expatriate workers in this worker fitnessscreening programme (3970 875) is an underestimate, presumably because of limitations in the reporting system. There were lower annual numbers of expatriate workers in this review than those recorded in other official sources. Data from the Ministry of Labour state the total number of workers coming to Saudi Arabia was approximately 1.2 million in 2008 and 1.12 million in 2009 [11]. It is understood that not all expatriate workers are registered in $\mathrm{MOH}$ records, and about one-third are examined in other governmental health sectors [11]. However, as we showed here, the registered number of expatriate workers in the $\mathrm{MOH}$ was still low. There are several reasons for this. First, not all the health regions are connected to the computerized reporting network (some still send faxed reports because the necessary infrastructure is lacking). Secondly, not all private authorized testing centres are yet connected to the network. Thirdly, there is limited coordination among other governmental health sectors and partners, such as the Ministry of Interior and Ministry of Labour. All these factors make it difficult for the $\mathrm{MOH}$ to accurately identify expatriate workers in Saudi Arabia.

The greatest drawback of the screening programme was that some of the data of unfit workers reported to the $\mathrm{MOH}$ were incomplete (e.g. missing worker code numbers and names of the external centres issuing the fitness certificates). These insufficiencies led to delays in identifying the external centres that had violated the rules, which meant that they were able to issue even greater numbers of inaccurate certificates. 
Among the limitations of this study is that the data review was based on the electronic records of the $\mathrm{MOH}$ database. This was insufficient in terms of providing certain variables, e.g. on the distribution of noncommunicable diseases by type. The paper records obtained from the $\mathrm{MOH}$ headquarters and regions were disorganized and difficult to review. There were few references in the literature to expatriate workers in Saudi Arabia, and those that were found were not recent.

\section{Conclusions}

Expatriate workers in Saudi Arabia originate from many countries, mostly in South-East Asia, and the highest rate of unfitness was found among workers from African countries. HBV was the main cause of unfitness, followed by noncommunicable diseases such as diabetes mellitus and hypertension. The lower rate of unfit workers found at the time of re-examination in Saudi Arabia compared with other GCC countries requires investigation and revision of the test standards and quality assurance processes in the Saudi-designated laboratories. The lower than expected numbers of registered expatriate workers in this worker fitness-screening programme suggest that reporting system for data from all authorized centres to the $\mathrm{MOH}$ must be improved.

Competing interests: None declared.

\section{References}

1. Cox R, Jeremijenko A, Doig KM. Expatriate health and welfare: the hidden costs of getting it wrong. Society of Petroleum Engineers Asia Pacific Health, Safety, and Security Environment Conference and Exhibition, 10-12 September 2007, Bangkok, Thailand (http://www.onepetro.org/mslib/servlet/ onepetropreview?id=SPE-108547-MS, accessed 29 May 2013).

2. Fasano U, Iqbal Z. GCC countries: from oil dependence to diversification. Washington DC, International Monetary Fund, 2003:16-17.

3. Population and housing census, 2010. Central Department of Statistics, Ministry of Economy and Planning of Saudi Arabia [online database] (http://www.cdsi.gov.sa/, accessed 29 May 2013).

4. Abahussain NA. Prevalence of intestinal parasites among expatriate workers in Al-Khobar, Saudi Arabia. Middle East Journal of Family Medicine, 2005, 3:17-21.

5. Longva AN. Keeping migrant workers in check: the Kafala system in the Gulf. Washington DC, Middle East Research and Information Project, 2003.

6. Rules and regulations for medical examination of expatriates recruited for work in the GCC states, 2010. Riyadh, Saudi Arabia, Executive Board of Health Ministers for GCC Countries, 2010:33-38.

7. Alzahrani AJ et al. Detection of hepatitis $\mathrm{C}$ virus and human immunodeficiency virus in expatriates in Saudi Arabia by antigen-antibody combination assays. Journal of Infection in Developing Countries., 2009, 3:235-238.

8. Mohammad KA, Koshak EA. A prospective study on parasites among expatriate workers in Al-Baha from 2009-2011, Saudi Arabia. Journal of the Egyptian Society of Parasitology, 2011, 41:423-432.

9. Matthews CM, Nelson MR. Self-rated health in a population of expatriate workers and partners in Riyadh, Saudi Arabia. Occupational Medicine, 2004, 54:585-586.

10. Albreiki HM, Al-Ali AK, Rayan AJ. Salmonella carriers among expatriate workers in Al-Qatif area. Saudi Journal of Gastroenterology, 2004, 10:140-143.

11. Expatriate workers statistics, 2009. Ministry of Labor of Saudi Arabia [online database] (http://portal.mol.gov.sa/en/Statistics/Pages/MolStatistics2009.aspx, accessed 29 May 2013).
12. Shah SA et al. HIV-infected workers deported from the Gulf States: impact on Southern Pakistan. International Journal of STD \& AIDS, 1999, 10:812-814.

13. Workshop on quality assurance of HIV and hepatitis testing, Report on an intercountry workshop, Kiev, Ukraine, 24-26 September 2003. Copenhagen, World Health OrganizationRegional Office fo Europe, 2003 (http://www.euro.who.int/ document/e82620.pdf, accessed 29 May 2013).

14. Hepatitis B. Fact sheet No. 204. World Health Organization [onlien factsheet] (http://www.who.int/mediacentre/factsheets/ fs204/en/, accessed 29 May 2013).

15. Alswaidi FM, O'Brien SJ. Premarital screening programmes for haemoglobinopathies, HIV and hepatitis viruses: review and factors affecting their success. Journal of Medical Screening, 2009, 16:22-28.

16. Mansoor AA, Salih Al, Al-Jaroudi DH. Screening of hepatitis B and $C$ and human immunodeficiency virus in infertile couples in Saudi Arabia. Saudi Medical Journal, 2011, 32:260-264.

17. Statistics book. Ministry of Health of Saudi Arabia (http://www. moh.gov.sa/en/Ministry/Statistics/Book/Pages/default.aspx, accessed 29 May 2013).

18. HIV infection statistics in Saudi Arabia for 2011. Okaz [in Arabic]. (http://www.okaz.com.sa/new/Issues/20111229/ Con20111229466105.htm, accessed 29 May 2013).

19. Jones S. Medical aspects of expatriate health: health threats. Occupational Medicine, 2000, 50:572-578.

20. Omar MS. A survey of bancroftian filariasis among South-East Asian expatriate workers in Saudi Arabia. Tropical Medicine and International Health, 1996, 1:155-160.

21. Hamdi SA, Ibrahim MA. Sexually transmitted diseases in domestic expatriate workers in Jeddah, Saudi Arabia. Annals of Saudi Medicine, 1997, 17:29-31.

22. Newson-Smith MS. Importing health conditions of expatriate workers into the United Arab Emirates. Asia-Pacific Journal of Public Health, 2010, 22(Suppl.):25-30.

23. Al-Mufti $S$ et al. Screening expatriate work force for HIV, HBV, and HCV infections in Kuwait. Kuwait Medical Journal, 2002, 34:24-27. 